Review

\title{
From A. rhizogenes RolD to Plant P5CS: Exploiting Proline to Control Plant Development
}

\author{
Maurizio Trovato *(D), Roberto Mattioli ${ }^{(D)}$ and Paolo Costantino \\ Department of Biology and Biotechnology, Sapienza University of Rome, 00185 Rome, Italy; \\ roberto.mattioli@uniroma1.it (R.M.); paolo.costantino@uniroma1.it (P.C.) \\ * Correspondence: maurizio.trovato@uniroma1.it; Tel.: +39-06-4991-2922
}

Received: 12 October 2018; Accepted: 1 December 2018; Published: 6 December 2018

check for updates

\begin{abstract}
The capability of the soil bacterium Agrobacterium rhizogenes to reprogram plant development and induce adventitious hairy roots relies on the expression of a few root-inducing genes (rol $A, B, C$ and $D$ ), which can be transferred from large virulence plasmids into the genome of susceptible plant cells. Contrary to rol $A, B$ and $C$, which are present in all the virulent strains of $A$. rhizogenes and control hairy root formation by affecting auxin and cytokinin signalling, rolD appeared non-essential and not associated with plant hormones. Its role remained elusive until it was discovered that it codes for a proline synthesis enzyme. The finding that, in addition to its role in protein synthesis and stress adaptation, proline is also involved in hairy roots induction, disclosed a novel role for this amino acid in plant development. Indeed, from this initial finding, proline was shown to be critically involved in a number of developmental processes, such as floral transition, embryo development, pollen fertility and root elongation. In this review, we present a historical survey on the rol genes focusing on the role of rolD and proline in plant development.
\end{abstract}

Keywords: plant development and organogenesis; proline biosynthesis; RolD; rol genes

\section{Hairy Roots and rol Genes}

Rhizobium rhizogenes, formerly known as Agrobacterium rhizogenes [1-5] is the etiological agent of the hairy root disease, consisting of abundant root proliferation at the site of bacterial infection. The capability of Rhizobium rhizogenes to induce hairy roots on susceptible dicotyledonous plants relies on its extraordinary ability to transfer a DNA fragment, called T-DNA, from a large Ri (root-inducing) plasmid to the genome of a plant cell [6-8]. The mechanism of T-DNA transfer [9] represents a natural form of genetic engineering, whose comprehension and exploitation has paved the way to the development of plant genetic transformation [10-13].

Hairy roots can be easily cultivated in vitro on hormone free medium [14] (Figure 1) and, in most plant species, can also be regenerated into whole fertile plants [15]. In addition, hairy roots produce unusual amino acid-sugar conjugates, called opines (Figure 2) which are not present in normal plant tissues. Depending on the specific Ri plasmid the transforming T-DNA comes from, one of four possible opines, that is agropine, cucumopine, mannopine and mikimopine, is synthesized by enzymes encoded by genes borne on the T-DNA and catabolized by enzymes encoded by genes located on the non-transferred plasmid portion. Because of the tight correlation between the synthesis of a given opine in hairy roots and the utilization of the same opine by the bacterium [16], a further opine-based classification of Agrobacterium strains has been proposed and will be adopted in this review. The T-DNA of all the Ri-plasmids have been characterized and sequenced [17-20]. The T-DNA of cucumopine-, mannopine- and mikimopine-type Ri plasmids turned out to consist in a continuous stretch of DNA, while the T-DNA of the agropine-type Ri plasmid is split in two T-DNA, called TR- and TL-DNA, which are independently transferred and integrated into the plant cell. Subsequent genetic work has 
clearly shown that the TL-DNA is uniquely responsible for hairy root induction, while the TR-DNA plays an accessory role to facilitate hairy root induction in some recalcitrant plant species. In a seminal work by White et al. [21] an extensive mutagenesis analysis was carried out, by transposon tagging, on the agropine-type pA4 plasmid. The genetic analysis led to the identification of four classes of mutations capable to affect the rooting phenotype and denominated, accordingly, rol (root loci) $A, B, C$ and $D$. To further identify their functions, different rol combinations were cloned into binary vectors and transferred to Agrobacterium [22] to be used either for infection experiments on different plant hosts or for generating transgenic plants. The first analyses confirmed that the rol genes were the only Ri T-DNA segments responsible for hairy root induction and showed that a DNA fragment encompassing rolA, $B$ and $C$ was almost as effective in inducing hairy roots as the whole Ri T-DNA [23]. Accordingly, because of the functional importance of $\operatorname{rol} A, B$ and $C$ and because these genes are present in all virulent strains of Agrobacterium rhizogenes, most of the studies initially focused on these oncogenes, particularly on rolB, while little attention was paid to rolD. Most of the aspects related to Agrobacterium, hairy roots and rolA, $B$ and $C$, have been covered by excellent reviews [24-26] and will not be further expanded.

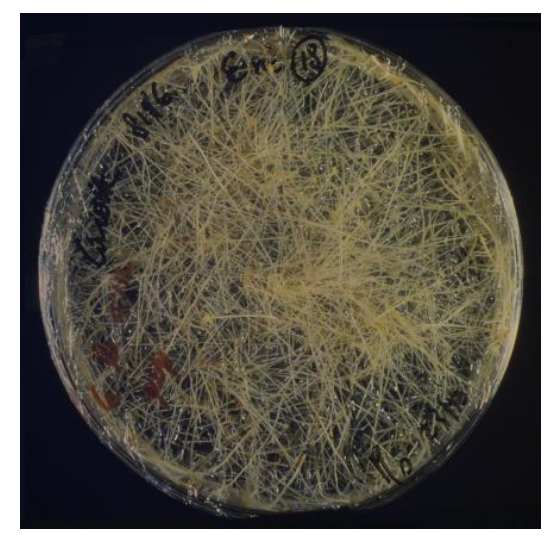

Figure 1. In vitro culture of roots induced on carrot discs by co-inoculation with an Agrobacterium strain containing a mannopine-type pRi8196. Once a hairy root culture is established, it can be maintained in vitro without the need of plant hormone supplementation. Fully fertile transgenic plants can be regenerated by these hairy roots.

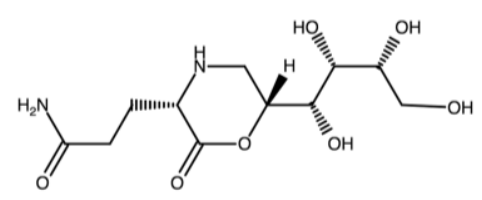

Agropine<smiles>NC(=O)CC[C@H](NC[C@H](O)[C@H](O)[C@H](O)[C@H](O)CO)C(=O)O</smiles>

Mannopine<smiles>O=C(O)CC[C@@]1(C(=O)O)N[C@@H](C(=O)O)Cc2[nH]cnc21</smiles>

Cucumopine<smiles>O=C(O)CC[C@]1(C(=O)O)N[C@@H](C(=O)O)Cc2[nH]cnc21</smiles>

Mikimopine

Figure 2. Chemical structure of agropine, cucumopine, mannopine and mikimopine, the four opines found in A. rhizogenes strains. The genes responsible for the synthesis of these unusual amino acid-sugar conjugates are borne on the T-DNA, while the genes coding for the catabolic enzymes are found on the non-transferred plasmid portion. 


\section{RolD}

As already noted, rolD is not present in all virulent $A$. rhizogenes strains and therefore plays a marginal role in hairy root induction. However, transformation experiments [27-29] showed that expression of rolD is developmentally regulated in and can deeply affect the development of plant cells. Tobacco plants expressing rolD driven by its own promoter have been reported to reach anthesis in average 60 days (in some cases as many as 75) before untransformed plants [28]. The inflorescence was richer and long-lasting, compared to controls plants and the overall morphology of the plants was deeply altered, with a strong reduction in height and with tiny and bract-like leaves. Furthermore, organogenesis experiments on thin cell layers (TCL) from rolD and control plants cultured on different synthetic media confirmed and extended in vitro the notion that rolD has the potentiality to enhance and anticipate flower formation [28]. Similar results were obtained in tomato [30] and Arabidopsis [31]. The small size typical of all rolD-expressing transgenic plants, may be accounted for by the early and abundant proliferation of axillary buds, leading to highly branched shoots. Down-regulation of CYP79F1/SUPERSHOOT / BUSHY (SPS), a gene involved in glucosinolate biosynthesis [32], was reported in Arabidopsis transformed with rolD [31]. Since SPS normally inhibits the formation of lateral shoots by altering cytokinin balance, the proliferation of axillary branches of Arabidopis transgenic for rolD may be accounted for by a (secondary) effect of rolD on SPS expression.

It is not clear how SPS downregulation can affect the cytokinin/auxin ratio, since the synthesis of indole glucosinolates in Arabidopsis proceeds from the transformation of tryptophane to indole-3-acetaldoxime catalysed by CYP79B2 and CYP79B3 [33], while CYP79F1 is involved in the biosynthesis of aliphatic glucosinolates [32,34]. However, CYP79F1/SPS has the potentiality to affect cytokinin/ auxin balance through the synthesis of a common aldoxime precursor. Consistently, a null CYP79F1 mutant (bus1-1f), totally devoid of short-chain methionine-derived glucosinolates, was also found enriched in indole-3-methyl-glucosinolate, indole-3-acetic acid and indole-3-acetonitrile [34].

Histochemical analysis of tobacco plants expressing the GUS reporter gene driven by the rolD promoter, revealed that this gene has a complex pattern of expression under strict developmental control [29]. Unlike other rol genes, which are always expressed in meristematic tissues, the promoter of rolD is not active in plant meristems but rather works in all growing and differentiating tissues throughout development, from the embryo to the adult plant. In particular, the expression of rolD characterizes the region of elongation and expansion of every tissue and organ. Intriguingly, as already mentioned, mutations in rolD prevent the T-DNA-induced hairy roots from elongating after initiation [21]. This suggests the possibility that rolD may be functionally involved in the process of elongation and/or maturation of roots and, possibly, of other organs.

A similarity search, based on a combination of iterative and noniterative methods, detected a highly significant sequence similarity between rolD and the gene coding for ornithine cyclodeaminase (OCD), an unusual enzyme of bacterial origin that catalyses the direct conversion of ornithine and NAD+ into proline and $\mathrm{NH}_{4}{ }^{+}$[35] (Figure 3). This bioinformatic prediction was experimentally confirmed by enzymatic assays on RolD expressed and purified in E. coli and on soluble extracts from plants overexpressing the oncogene under the control of a CaMV35S promoter. The enzymatic assays revealed a specific ornithine-dependent proline production, associated to NAD+ reduction, that could only be accounted for by OCD activity. No functional OCDs have been detected so far in plants [36], where ornithine is converted to proline only via pyridoxal phosphate-dependent reactions. OCD seems to be a specialized enzyme that has been found only in a limited number of prokaryotic species, such as Agrobacterium, Sinorhizobium, Rhodobacterium and Brucella as well as in some extremophile archaea, such as Archeoglobus and Methanobacterium, where it is involved in the catabolism of unusual carbon and nitrogen sources like opines or methane. Interestingly, in A. tumefaciens OCD is encoded by genes localized in the non-transferred part of the Ti plasmid [7,37] to be used for opine catabolism, while in $A$. rhizogenes, OCD has become part of the T-DNA and it is expressed only in the plant cells. Intriguingly, in animals the mu-crystallins family of proteins shares significant similarities with OCD. This is not surprising, because in the mammalian eye often lens proteins derive from metabolic enzymes or 
stress proteins, which acquire reflective properties while, in some cases, maintaining their original metabolic activity [38].

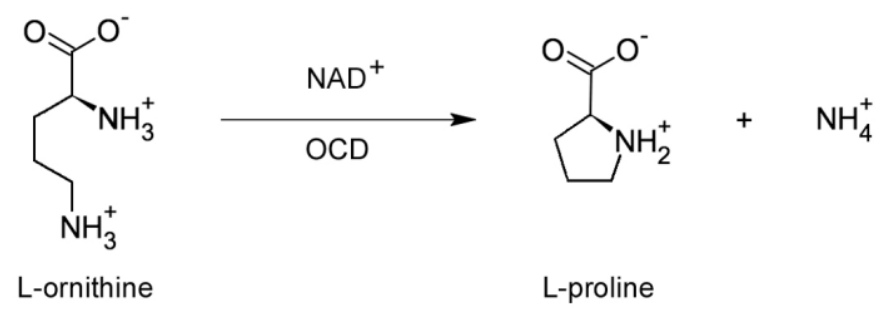

Figure 3. Proline synthesis from ornithine. The enzyme ornithine cyclo deaminase (OCD), an enzyme frequently found in bacteria but uncommon in plants, catalyses the $\mathrm{NAD}^{+}$-dependent conversion of ornithine into proline and $\mathrm{NH}_{4}{ }^{+}$.

Since rolD is only present in the TL-DNA of the agropine-type Ri plasmids, its expression seems not strictly required for hairy root elongation. Although not experimentally demonstrated, it is tempting to speculate that $r o l D$, similarly to the ancillary role played by the $\mathrm{T}_{\mathrm{R}}$-DNA-borne $i a a H$ and iaaM genes in the process of hairy root induction, might play an auxiliary role in hairy root elongation by providing more proline in hosts with low levels of endogenous proline or during environmental stresses requiring higher proline demand. In support of this hypothesis, proline has been shown to accumulate during the elongation of the maize primary roots at low water potential [39].

As alternative explanation, other genes, either belonging to the Ri T-DNA or to the plant genome itself, could functionally substitute for rolD expression. This hypothesis is based on the work of Levesque et al (1988) [40] who observed that the Ri TL-DNA genes are functionally redundant and may derive from a common ancestral T-DNA. Redundancy, according to authors, would serve as an adaptive strategy to ensure function in a variety of host species and environmental conditions [40]. In the case of rolD, a recent duplication has apparently occurred between ORF 15 (rolD) and the ORFs 18 and 17, which, assembled together, restore a direct repetition of rolD [40]. Furthermore, portions of the Ri TL-DNA plasmid, including rolD, have been detected in the genome of some plant species (ct-TDNA), probably as a result of ancient Agrobacterium transformations [41,42]. It must be noted that, since OCD activity, in addition to proline, also produces NH4, a major nitrogen source which behaves as a signalling molecule capable of triggering multiple physiological and morphological responses in plants [43], we cannot rule out the possibility that some of the developmental alterations attributed to OCD may be accounted for, or contributed to, a perturbed ammonium homeostasis.

\section{The Role of Proline in Plant Development}

The discovery that RolD is a proline-synthesizing enzyme involved in root elongation [21,29] but also in flowering time $[21,28,30]$, implied the possibility that this cyclic amino acid may have a role in plant development. It was already well-established that proline, in addition to its role in protein synthesis, is involved in the plant cell response to many types of stresses, essentially because a strong proline accumulation is observed soon after stress occurrence in many plant species [44].

However, proline accumulation was also described, in non-stressed conditions, in the tissues and organs of different plant species, particularly during the reproductive phase [45-50], supporting the idea that proline may play a role in plant reproductive development in normo-osmotic conditions. In the total amino acid pool of Arabidopsis, the percentage of proline raises from 1-3\% in vegetative tissues before floral transition, to $26 \%$ in reproductive tissues after floral transition [49]. Similarly, Schwacke et al. (1999) [50] observed that the content of free proline in tomato flowers was 60-fold higher than in any other organ analysed. Although proline is a relatively common amino acid in plants, because of the frequent occurrence of long stretches of proline or hydroxyproline residues in cell wall proteins, particularly extensins [51], it is unlikely that, in non-stressed conditions, such large amount of proline can be accumulated for the needs of protein synthesis. 
Differently from OCD, which catalyses the direct conversion of ornithine to proline, in higher plants proline is mainly synthesized in the cytosol from glutamate in a two-step reaction involving the enzyme $\delta$-pyrroline-5-carboxylate synthetase (P5CS) and $\delta$-pyrroline-5-carboxylate reductase (P5CR). Subsequently, proline is exported to the mitochondrion where it is catabolized back to glutamate by the enzymes proline dehydrogenase (ProDH) and $\delta$-pyrroline-5-carboxylate synthetase P5CDH [44]. An alternative route starting from ornithine and mediated by ornithine $\delta$-aminotransferase $(\delta \mathrm{OAT})$ has also been reported [52], at least in some physiological conditions but its functional significance in maintaining proline homeostasis is strongly controversial [53,54].

The genes coding for the anabolic and catabolic enzymes of proline synthesis are highly conserved among plant species, although P5CS and ProDH, the genes coding for the rate-limiting steps of the anabolic and, respectively, catabolic pathways, may be present in multiple variants [55]. In Arabidopsis, P5CS is encoded by two paralog genes P5CS1 and P5CS2 [56], whose deduced amino acid sequences share $98 \%$ amino acid identity. In spite of the high similarity of these isoforms, P5CS1 and P5CS2 have a different tissue specificity and play non-redundant but partially overlapping functions, as inferred by the analysis of transgenic Arabidopsis carrying mutations in either P5CS1 or P5CS2 [57,58]. P5CS1 is responsive to stress induction, while P5CS2 is constitutively expressed at low levels in all tissues and organs and at high level in meristematic tissues, floral organs and in embryos $[57,58]$.

\subsection{Floral Transition}

Consistent with the strong anticipation and stimulation of flowering induced by the ectopic expression of rolD [28,30,31], a number of authors reported, in absence of stressing stimuli, upregulation of both proline biosynthesis (P5CS, P5CR) and transport genes (ProT) in reproductive tissues [50,59,60], such as flowers, inflorescences and anthers, suggesting a possible role of proline in flowering. Intriguingly, the expression of the proline catabolic genes $(\mathrm{ProDH}, \mathrm{P} 5 \mathrm{CDH})$ was also reported to increase in reproductive tissues under normo-osmotic conditions [61-63], in striking contrast with the strong downregulation of these genes observed under stressed conditions $[64,65]$. In agreement with these data, Kavi Kishor et al. (1995) [66] reported that constitutive overexpression of P5CS1 in tobacco plants enhances flower development under drought conditions, while Nanjo et al. (1999) [67] reported that antisense expression of P5CS1 inhibits bolting in Arabidopsis. Arabidopsis p5cs1 mutants and to a greater extent, $p 5 c s 1 p 5 c s 2 / P 5 C S 2$ sesquimutants, exhibited a strong delay in floral transition $[58,68,69]$ (Figure 4A), while transgenic Arabidopsis overexpressing P5CS1 under the control of the strong and constitutive CaMV35S promoter, showed a striking anticipation of flowering time and a proliferation of coflorescences, particularly in short day conditions [68]. In transgenic 35S::P5CS1 plants, the expression of the recombinant P5CS1 was downregulated after flower transition, along with the endogenous allele of P5CS1 and P5CS2, and, accordingly, P5CS1 was overexpressed only for a short time, up to floral transition [68]. Altogether, these data suggest that proline plays a key role in flower transition, bolting and coflorescence architecture.

Presently, the molecular mechanism through which proline affects flowering time is not clear but it seems quite different from the mechanism through which proline protects plant cells from stress injuries [70]. One major difference between these mechanisms is the concentration of proline involved: during floral transition proline reaches only a localized and transient increase in the shoot apical meristem (SAM), while under stress conditions, it accumulates at high levels in all the tissues of the plant [68]. The accumulation of proline measured in 35S-P5CS1 plants (up to 3-fold the level of the wildtype), seems modest compared to that achieved under stress, where proline levels are 10 to 20-fold higher than in unstressed plants [68], suggesting that this amino acid may behave as a floral signal able to interact with flower regulators. It is well known that floral transition, i.e., the transition from a vegetative shoot apical meristem (SAM) to a floral SAM, involves a profound change in the identity of the apical meristem that starts producing flowers rather than leaves [71]. This switch to vegetative to reproductive development is regulated by a number of environmental and endogenous inputs, which converge to regulate master flowering regulators, 
which, in turn, activate floral identity genes. By genetic analysis four major pathways have been identified, photoperiodic, autonomous, vernalisation and gibberellin pathway [72-74], which are controlled by the master regulators CONSTANS (CO) and FLOWERING LOCUS C (FLC), which, in turn, control the floral integrators LEAFY (LFY), SUPPRESSOR OF CONSTANS 1 (SOC1) and FLOWERING TIME (FT) to eventually activate the floral identity genes APETALA 1 (AP1), APETALA 2 (AP2), FRUITFULL (FUL) and CAULIFLOWER (CAL). In agreement with the hypothesis that proline may behave as a floral signalling molecule, P5CS2 has been identified as an early regulatory target of CONSTANS (CO), a master transcriptional regulator of the photoperiodic pathway [75]. However, because of the importance of proline as redox buffer [76] and ROS scavenger [77], we cannot rule out the possibility that proline may act as an active metabolite involved in metabolic signalling [78]. Overall, the body of accumulated evidence points to proline as a modulator of floral transition although a full comprehension of its mechanism of action and of the floral pathway it interacts with is still to be gained.

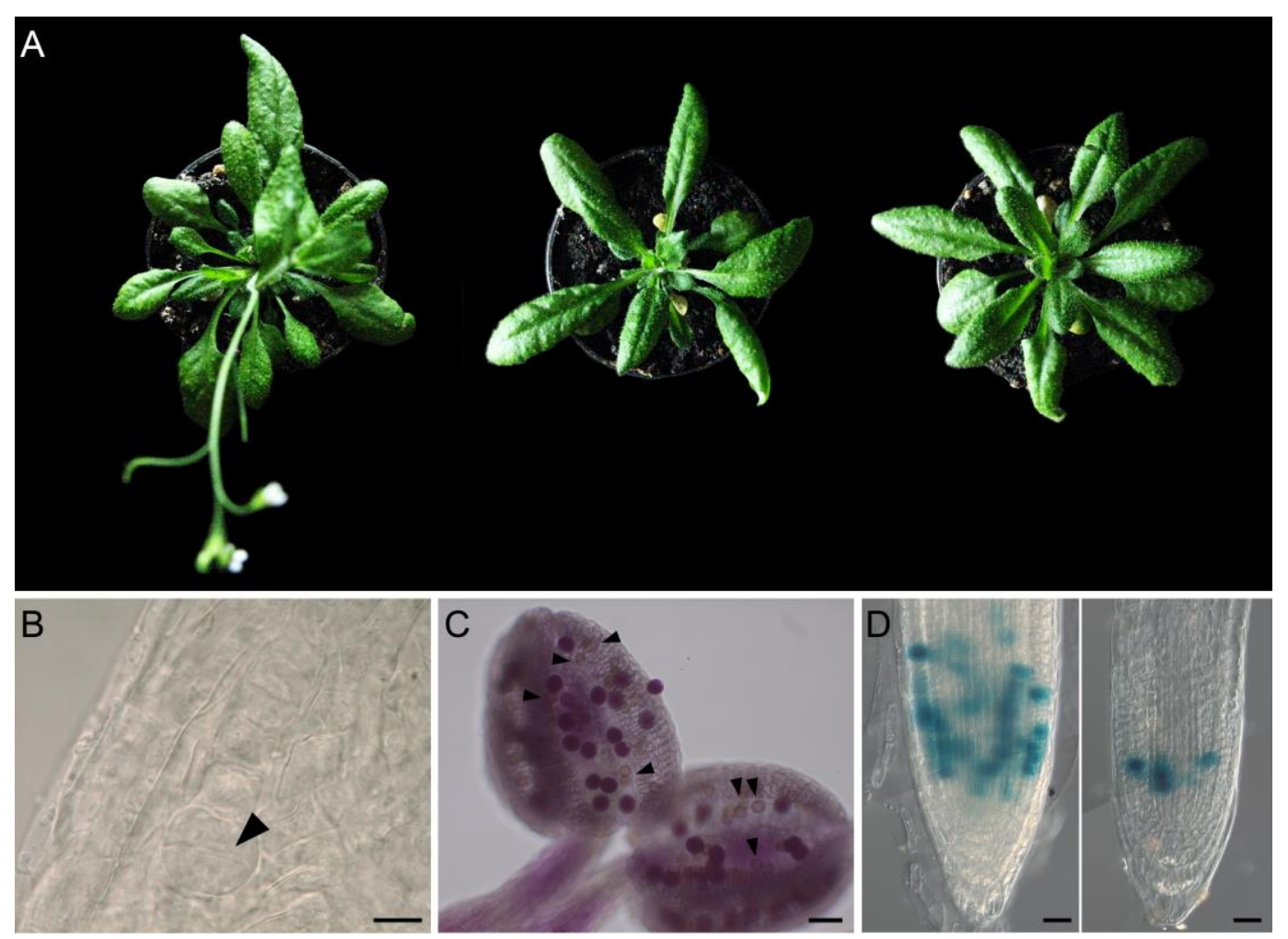

Figure 4. Effects of proline on plant development. (A) Arabidopsis p5cs1 mutants (middle) and to a greater extent, $p 5 c s 1 p 5 c s 2 / P 5 C S 2$ sesquimutants (right), defective in proline synthesis, are late flowering, compared to a wildtype (left) [68]. (B) Aberrant orientations of cellular division planes observed in an octant embryo from a segregating population of heterozygous $p 5 c s 2 /+$ [58]. (C) Arabidopsis anthers from $p 5 c s 1 p 5 c s 2 / P 5 C S 2$ sesquimutants stained with the vital Alexander's staining show a population of stained and viable pollen grains mixed with a population of unstained and unviable aberrant pollen grains (indicated by arrows) [69,79]. (D) GUS staining of CYCB:GUS roots in a wildtype (leftmost side) and a p5cs1 p5cs2/P5CS2 (rightmost side) background reveals the effects of proline on cell division [80]. Arrows show the aberrant division planes in an octant embryo in (B) and the unstained, unviable pollen grains in a p5cs1 p5cs2/P5cs2 anther in C. Bars $=10 \mu \mathrm{m}(B), 50 \mu \mathrm{m}(\mathrm{C})$ and $20 \mu \mathrm{m}(\mathrm{D})$.

\subsection{Embryo Development}

Proline seems to play an important role also in plant embryogenesis. Quite surprisingly, despite the high sequence similarity shared by P5CS1 and P5CS2 and although both genes share the same pattern of expression in shoot apical meristems and embryos [57,58], p5cs2 but not p5cs1 
mutants, are embryo lethal suggesting a specific role of P5CS2 in embryogenesis. The embryo defects (Figure 4B) can be partially [57,58] or totally [69] complemented by treatment with L-proline suggesting that mutations in P5CS2 specifically affect proline accumulation in developing seeds. The reason for such striking differences between P5CS1 and P5CS2 are not fully understood but it may be related to different subcellular localization of these two proteins in the embryo, as proposed by Szekely et al (2008) [57] who detected a P5CS1:GFP fusion protein outside the cytoplasm within subcellular bodies, while P5CS2:GFP had a cytoplasmic localization. A microscopic analysis of the mutant embryos revealed a number of aberrations typically associated with defects in cell cycle progression, such as anomalous orientations of the cellular division planes (Figure 4B), multi-nucleate suspensor cells and adventitious embryos [58], suggesting a possible relation between proline and cell cycle.

\subsection{Pollen Fertility}

One the best-known and less-explained fact on pollen composition is the exceedingly large amount of proline found in different plant species [49,50,81-83] suggesting a special role for proline in pollen development and function. At present, it is not known how proline can accumulate in pollen in such large quantities. In principle, proline could be synthesized inside gametophytic pollen grains, in surrounding sporophytic tissues, such as the tapetum or the intermediate layer, or be transported through phloem or xylem vessels from far away tissues. Because single, double and triple knockout mutants for all the genes belonging to the AtProT family-the best known group of proline transporter in plants-showed no differences, compared to wildtype, [84] and because microarray data detect strong expression of proline biosynthesis genes in pollen and anthers [85], proline accumulation in pollen grains likely derive from endogenous synthesis either in sporophytic or in gametophytic tissues of the anther.

Since pollen grains are subjected to a process of natural dehydration during their maturation, a role for proline as a compatible osmolyte has been proposed by some authors [49], while others [86] postulated that this amino acid may act as source of energy or metabolic precursor to fuel the rapid elongation of the pollen tube. A sound scientific base to settle this contrasting views was independently given by two research groups $[69,79]$ who demonstrated, by a combination of genetic and physiological experiments, that a $p 5 c s 1 p 5 c s 2 / P 5 C S 2$ sesquimutant, homozygous for $p 5 c s 1$ and heterozygous for $p 5 c s 2$, was strongly impaired in pollen fertility [87].

The fertility defects of the sesquimutants were accounted for by defects in pollen grains, a number of which-presumably those with a $p 5 c s 1, p 5 c s 2$ haploid genotype-were degenerated and unviable (Figure 4C). The proline content of the sesquimutant pollen population was measured and found to be less than a third compared to wildtype pollen. Moreover, exogenous proline supplied from the beginning of anther development was shown to partially complement both morphological and functional defects of the aberrant pollen grains. All in all, these data indicate that proline is required for pollen development and fertility and further corroborate the notion of the crucial importance of proline in reproductive development.

\subsection{Root Elongation}

In addition to its role in plant reproductive development, a novel role as modulator of root growth has been recently ascribed to proline [80]. In plants, postembryonic root growth is driven by the activity of the root meristem, which continuously regenerates itself in the staminal niche, while generating transit-amplifying cells, which undergo additional division in the proximal meristem and eventually, differentiate in the meristem transition zone. The balance between cell proliferation and cell differentiation determines root meristem size and, in turn, root growth and is largely controlled by plant hormones, particularly cytokinin and auxin [88].

The size of the root meristem, expressed as the number of cortex cells spanning from the quiescent centre (QC) to the first elongated cell in the transition zone (TZ) [89], was analysed in $p 5 c s 1$ p5cs2/P5CS2 sesquimutants relative to wildtype. Proline-deficient mutants were found to have root meristems 
remarkably smaller than the wildtype and the addition of micromolar concentrations of exogenous proline fully rescued the sesquimutant root meristem to wildtype size. Importantly, the effect of exogenous proline was also tested on wildtype roots and shown to have a specific and dose-dependent stimulatory effect at low concentrations and an inhibitory effect at high concentrations [80].

Considering the role played by rolD in the hairy roots syndrome, it not surprising that proline can modulate root elongation. Indeed, in the genesis of hairy roots RolD/OCD is involved in the elongation of roots generated by the combined action of RolA, B and C [21]. In addition, exogenous proline at micromolar concentration was shown to induce elongation of both primary and secondary roots in Arabidopsis [58].

The action of proline on root meristem seems independent of the plant hormones auxin, cytokinin and gibberellin as shown by a combination of pharmacological, molecular and genetic experiments [80]. Proline was found to regulate cell division in early stages of root development modulating the expression of CYCB1;1, the gene coding for the G2/M-specific CYCLINB1;1 (Figure 4D).

Other hormone-independent mechanisms are known to modulate root growth, such as the superoxide/hydrogen peroxide ratio reported by Tsukagoshi et al. (2010) [90] but the case of proline is quite surprising because the accumulation of this amino acid in the root is under strict abscisic acid (ABA) control under stress conditions [91]. However, proline has also been shown to be regulated by non-ABA-dependent factors $[60,92]$ and it is possible that two parallel signalling pathways can independently control proline-dependent root regulation under stressed and, respectively, non-stressed conditions.

\section{Conclusions and Perspectives}

Much like the hairy root syndrome, which was originally thought as a simpler variant of the crown gall disease but eventually turned out to be a highly sophisticated and, as yet, not fully understood biological mechanism, the role of proline in plant development is unveiling unexpected complexities in plant development. Thanks to the study of rolD, we now know that proline can modulate the size of the root meristem independently of plant hormones and finely tune development in reproductive organs, although we are still far from a full comprehension of the underlying mechanisms of action. In a way, much like plant hormones, proline may behave as a second messenger. Because of the remarkable chemical-physical properties of this cyclic amino acid, however, a mechanism mediated by or dependent on metabolic regulations cannot be ruled out.

The long scientific journey from hairy roots to RolD to plant P5CS has produced more open questions than definitive answers. Our understanding of the genetic and molecular mechanisms through which proline exerts its effects on plant development is still rudimentary. We do not know whether the effects of proline on different developmental processes are mediated by different mechanisms or share a common molecular machinery. Clearly, further work is needed to fully understand the complex molecular mechanism/s by which proline can finely tune developmental processes as diverse as hairy root elongation, floral transition or pollen fertility.

Author Contributions: M.T. and P.C. wrote the review. R.M. collected the bibliography and prepared the figures. All the authors checked the draft and discussed improvements.

Funding: This work was partially supported by research grants from Sapienza Università to MT, from the Italian Ministry of Education, University and Research (Progetti di Ricerca di Interesse Nazionale) to PC.

Acknowledgments: We wish to dedicate this review to the memory of Prof. Domenico Mariotti, one of the first researchers in Italy to pioneer experiments on Agrobacterium-mediated plant genetic transformation and regeneration, paving the way to the development of the modern plant genetic engineering and leading to exciting new discoveries on plant development.

Conflicts of Interest: The authors declare no conflicts of interest. 


\section{References}

1. Holmes, B.; Roberts, P. The Classification, Identification and Nomenclature of Agrobacteria. J. Appl. Microbiol. 1981, 50, 443-467. [CrossRef]

2. Young, J.M.; Kuykendall, L.D.; Martínez-Romero, E.; Kerr, A.; Sawada, H. A revision of Rhizobium Frank 1889, with an emended description of the genus, and the inclusion of all species of Agrobacterium Conn 1942 and Allorhizobium undicola de Lajudie et al. 1998 as new combinations: Rhizobium radiobacter, R. rhizogenes, R. rubi, R. undicola and R. vitis. Int. J. Syst. Evol. Microbiol. 2001, 51, 89-103. [CrossRef] [PubMed]

3. Young, J.B. Implications of alternative classifications and horizontal gene transfer for bacterial taxonomy. Int. J. Syst. Evol. Microbiol. 2001, 51, 945-953. [CrossRef] [PubMed]

4. Young, J.M.; Kuykendall, L.D.; Martínez-Romero, E.; Kerr, A.; Sawada, H. Classification and nomenclature of Agrobacterium and Rhizobium-A reply to Farrand et al. (2003). Int. J. Syst. Evol. Microbiol. 2003, 53, 1689-1695. [CrossRef] [PubMed]

5. Kerr, A.; Brisbane, P.G. Agrobacterium. In Plant Bacterial Diseases, A Diagnostic Guide; Fahy, P.C., Persley, G.J., Eds.; Academic Press: Sydney, Australia, 1983; pp. 27-43.

6. Chilton, M.-D.; Drummond, M.H.; Merio, D.J.; Sciaky, D.; Montoya, A.L.; Gordon, M.P.; Nester, E.W. Stable incorporation of plasmid DNA into higher plant cells: The molecular basis of crown gall tumorigenesis. Cell 1977, 11, 263-271. [CrossRef]

7. Chilton, M.-D.; Tepfer, D.A.; Petit, A.; David, C.; Casse-Delbaurt, F.; Tempé, J. Agrobacterium rhizogenes inserts T-DNA into the genomes of the host plant root cells. Nature 1982, 295, 432-434. [CrossRef]

8. Lemmers, M.; De Beuckeleer, M.; Holster, P.; Zambryski, P.; De Picker, A.; Hernalsteens, J.P.; Van Montagu, M.; Schell, J. Internal organization, boundaries and integration of Ti-plasmid DNA in nopaline crown gall tumours. J. Mol. Biol. 1980, 144, 353-376. [CrossRef]

9. Gelvin, S.B. Agrobacterium Mediated Plant Transformation: The Biology behind the "Gene-Jockeying" Tool. Microbiol. Mol. Biol. Rev. 2003, 67, 16-37. [CrossRef]

10. Hwang, H.-H.; Yu, M.; Lai, E.-M. Agrobacterium-Mediated Plant Transformation: Biology and Applications. Arabidopsis Book 2017, 15, e0186. [CrossRef]

11. Rugini, E.; Pellegrineschi, A.; Mencuccini, M.; Mariotti, D. Increase of rooting ability in the woody species kiwi (Actinidia deliciosa A. Chev.) by transformation with Agrobacterium rhizogenes rol genes. Plant Cell Rep. 1991, 10, 291-295. [CrossRef]

12. Fontana, G.S.; Santini, L.; Caretto, S.; Frugis, G.; Mariotti, D. Genetic transformation in the grain legume Cicer arietinum L. (chickpea). Plant Cell Rep. 1993, 12, 194-198. [CrossRef] [PubMed]

13. Frugis, G.; Caretto, S.; Santini, L.; Mariotti, D. Agrobacterium rhizogenes rol genes induce productivity-related phenotypical modifications in "creeping-rooted" alfalfa types. Plant Cell Rep. 1995, 14, 488-492. [CrossRef] [PubMed]

14. White, F.F.; Braun, A.C. A cancerous neoplasm of plants. Cancer Res. 1942, 2, 597-617.

15. Spanò, L.; Costantino, P. Regeneration of plants from callus cultures of roots induced by Agrobacterium rhizogenes on tobacco. J. Phytopathol. 1982, 106, 87-92. [CrossRef]

16. Petit, A.; Delhaye, S.; Tempé, J.; Morel, G. Recherches sur les guanidines des tissus de crown gall. Mise en évidence d'une relation biochimique spécifique entre les souches d'Agrobacterium tumefaciens et les tumeurs qu'elles induisent. Physiol. Vég. 1970, 8, 205-213.

17. Slightom, J.L.; Durand-Tardiff, M.; Jouanin, L.; Tepfer, D. Nucleotide sequence analysis of TL-DNA of Agrobacterium rhizogenes agropine type plasmid. Identification of open reading frames. J. Biol. Chem. 1986, 261, 108-121. [PubMed]

18. Hansen, G.; Larribe, M.; Vaubert, D.; Tempé, J.; Biermann, B.J.; Montoya, A.L.; Chilton, M.D.; Brevet, J. Agrobacterium rhizogenes pRi8196 T-DNA: Mapping and DNA sequence of functions involved in mannopine synthesis and hairy root differentiation. Proc. Natl. Acad. Sci. USA 1991, 88, 7763-7767. [CrossRef]

19. Tanaka, N.; Ikeda, T.; Oka, A. Nucleotide Sequence of the rol Region of the Mikimopine-type Root-inducing Plasmid pRi1724. Biosci. Biotechnol. Biochem. 1994, 58, 548-551. [CrossRef] 
20. Mankin, S.L.; Hill, D.S.; Olhoft, P.M.; Toren, E.; Wenck, A.R.; Nea, L.; Xing, L.; Brown, J.A.; Fu, H.; Ireland, L.; et al. Disarming and sequencing of Agrobacterium rhizogenes strain K599 (NCPPB2659) plasmid pRi2659. In Vitro Cell. Dev. Biol. Plant 2007, 43, 521-535. [CrossRef]

21. White, F.F.; Taylor, B.H.; Huffman, G.A.; Nester, E.W. Molecular and genetic analysis of the transferred DNA regions of the root-inducing plasmid of Agrobacterium rhizogenes. J. Bacteriol. 1985, 164, 33-44.

22. Cardarelli, M.; Mariotti, D.; Pomponi, M.; Spanò, L.; Capone, I.; Costantino, P. Agrobacterium rhizogenes T-DNA genes capable of inducing hairy root phenotype. Mol. Gen. Genet. 1987, 209, 475-480. [CrossRef] [PubMed]

23. Capone, I.; Spanò, L.; Cardarelli, M.; Bellincampi, D.; Petit, A.; Costantino, P. Induction and growth properties of carrot roots with different complements of Agrobacterium rhizogenes T-DNA. Plant Mol. Biol. 1989, 13, $43-52$.

24. Kado, C.I. Historical account on gaining insights on the mechanism of crown gall tumorigenesis induced by Agrobacterium tumefaciens. Front. Microbiol. 2014, 5, 1-15. [CrossRef] [PubMed]

25. Binns, A.N.; Costantino, P. The Agrobacterium Oncogenes. In The Rhizobiaceae; Spaink, H.P., Kondorosi, A., Hooykaas, P.J.J., Eds.; Springer: Dordrecht, The Netherlands, 1998. [CrossRef]

26. Costantino, P.; Capone, I.; Cardarelli, M.; De Paolis, A.; Mauro, M.L.; Trovato, M. Bacterial plant oncogenes: The rol genes' saga. Genetica 1994, 94, 203-211. [CrossRef] [PubMed]

27. Leach, F.; Aoyagi, K. Promoter analysis of the highly expressed rolC and roID root-inducing genes of Agrobacterium rhizogenes: Enhancer and tissue-specific DNA determinants are dissociated. Plant Sci. 1991, 79, 69-76. [CrossRef]

28. Mauro, M.L.; Trovato, M.; De Paolis, A.; Gallelli, A.; Costantino, P.; Altamura, M.M. The plant oncogene rolD stimulates flowering in transgenic tobacco plants. Dev. Biol. 1996, 180, 693-700. [CrossRef] [PubMed]

29. Trovato, M.; Mauro, M.L.; Costantino, P.; Altamura, M.M. The rolD gene from Agrobacterium rhizogenes is developmentally regulated in transgenic tobacco. Protoplasma 1997, 197, 111-120. [CrossRef]

30. Bettini, P.; Michelotti, S.; Bindi, D.; Giannini, R.; Capuana, M.; Buaiatti, M. Pleiotropic effect of the insertion of Agrobacterium rhizogenes rolD gene in tomato (Lycopersicon esculentum Mill). Theor. Appl. Genet. 2003, 107, 831-836. [CrossRef]

31. Falasca, G.; Altamura, M.M.; D’Angeli, S.; Zaghi, D.; Costantino, P.; Mauro, M.L. The rolD oncogene promotes axillary bud and adventitious root meristems in Arabidopsis. Plant Physiol. Biochem. 2010, 48, 797-804. [CrossRef]

32. Tantikanjana, T.; Mikkelsen, M.D.; Hussain, M.; Halkier, B.A.; Sundaresan, V. Functional analysis of the tandem duplicated P450 genes SPS/BUS/CYP79F1 and CYP79F2 in glucosinolate biosynthesis and plant development by Ds transpo sition generated double mutants. Plant Physiol. 2004, 135, 840-848. [CrossRef]

33. Hull, A.K.; Vij, R.; Celenza, J.L. Arabidopsis cytochrome P450s that catalyze the first step of tryptophan-dependent indole-3-acetic acid biosynthesis. Proc. Natl. Acad. Sci. USA 2000, 97, 2379-2384. [CrossRef] [PubMed]

34. Reintanz, B.; Lehnen, M.; Reichelt, M.; Gershenzon, J.; Kowalczyk, M.; Sandberg, G.; Godde, M.; Uhl, R.; Palme, K. Bus, a bushy Arabidopsis CYP79F1 knockout mutant with abolished synthesis of short-chain aliphatic glucosinolates. Plant Cell 2001, 13, 351-367. [CrossRef] [PubMed]

35. Trovato, M.; Maras, B.; Linhares, F.; Costantino, P. The plant oncogene rolD encodes a functional ornithine cyclodeaminase. Proc. Natl. Acad. Sci. USA 2001, 98, 13449-13453. [CrossRef] [PubMed]

36. Sharma, S.; Shinde, S.; Verslues, P.E. Functional characterization of an ornithine cyclodeaminase-like protein of Arabidopsis thaliana. BMC Plant Biol. 2013, 13, 182. [CrossRef] [PubMed]

37. Thomashow, M.F.; Nutter, A.L.; Montoya, A.L.; Gordon, M.P.; Nester, E.W. Integration and organization of Ti plasmid sequences in crown gall tumors. Cell 1980, 19, 729-739. [CrossRef]

38. Piatigorsky, J.; Kantorow, M.; Gopal-Srivastava, R.; Tomarev, S.I. Recruitment of enzymes and stress proteins as lens crystallins. EXS 1994, 71, 241-250. [PubMed]

39. Verslues, P.E.; Sharp, R.E. Proline accumulation in maize (Zea mays L.) primary roots at low water potentials. II. Metabolic source of increased proline deposition in the elongation zone. Plant Physiol. 1999, 119, 1349-1360. [CrossRef]

40. Levesque, H.; Delepelaire, P.; Rouzé, P.; Slightom, J.L.; Tepfer, D. Common evolutionary origin of the central portions of the Ri TL-DNA of Agrobacterium rhizogenes and the Ti T-DNAs of Agrobacterium tumefaciens. Plant Mol. Biol. 1988, 11, 731-744. [CrossRef] 
41. Furner, I.J.; Huffman, G.A.; Amasino, R.M.; Garfinkel, D.J.; Gordon, M.P.; Nester, E.W. An Agrobacterium transformation in the evolution of the genus Nicotiana. Nature 1986, 319, 422. [CrossRef]

42. White, F.F.; Garfinkel, D.J.; Huffman, G.A.; Gordon, M.P.; Nester, E.W. Sequences homologous to Agrobacterium rhizogenes T-DNA in the genomes of uninfected plants. Nature 1983, 301, 348. [CrossRef]

43. Liu, Y.; von Wirén, N. Ammonium as a signal for physiological and morphological responses in plants. J. Exp. Bot. 2017, 68, 2581-2592. [CrossRef] [PubMed]

44. Trovato, M.; Mattioli, R.; Costantino, P. Multiple Roles of Proline in Plant Stress Tolerance and Development. Rend. Lincei Sci. Fis. Nat. 2008, 19, 325-346. [CrossRef]

45. Vansuyt, G.; Vallee, J.-C.; Prevost, J. La pyrroline-5-carboxylate réductase et la proline déhydrogénase chez Nicotiana tabacum var. Xanthi n.c. en fonction de son développement. Physiol. Vég. 1979, 19, 95-105.

46. Venekamp, J.H.; Koot, J.T.M. The sources of free proline and asparagine in field bean plants, Vicia faba L., during and after a short period of water withholding. J. Plant Physiol. 1988, 32, 102-109. [CrossRef]

47. Mutters, R.G.; Ferreira, L.G.R.; Hall, A.E. Proline content of the anthers and pollen of heat-tolerant and heat-sensitive cowpea subjected to different temperatures. Crop Sci. 1989, 29, 1497-1500. [CrossRef]

48. Walton, E.F.; Clark, C.J.; Boldingh, H.L. Effect of hydrogen cyanamide on amino acid profiles in kiwifruit buds during bud-break. Plant Physiol. 1991, 97, 1256-1259. [CrossRef] [PubMed]

49. Chiang, H.H.; Dandekar, A.M. Regulation of proline accumulation in Arabidopsis thaliana (L) Heynh during development and in response to desiccation. Plant Cell Environ. 1995, 18, 1280-1290. [CrossRef]

50. Schwacke, R.; Grallath, S.; Breitkreuz, K.E.; Stransky, E.; Stransky, H.; Frommer, W.B.; Rentsch, D. LeProT1, a transporter for proline, glycine betaine, and gamma-amino butyric acid in tomato pollen. Plant Cell 1999, 11, 377-392. [CrossRef]

51. Snowalter, A.M. Structure and function of plant cell wall proteins. Plant Cell 1993, 5, 9-23. [CrossRef]

52. Roosens, N.H.; Thu, T.T.; Iskandar, H.M.; Jacobs, M. Isolation of the ornithine-delta-aminotransferase cDNA and effect of salt stress on its expression in Arabidopsis thaliana. Plant Physiol. 1998, 117, 263-271. [CrossRef]

53. Funck, D.; Stadelhofer, B.; Koch, W. Ornithine- $\delta$-aminotransferase is essential for arginine catabolism but not for proline biosynthesis. BMC Plant Biol. 2008, 8, 40. [CrossRef] [PubMed]

54. Winter, G.; Todd, D.C.; Trovato, M.; Forlani, G.; Funck, D. Physiological implications of arginine metabolism in plants. Front. Plant Sci. 2015, 6, 1-14. [CrossRef] [PubMed]

55. Fichman, Y.; Gerdes, S.Y.; Kovács, H.; Szabados, L.; Zilberstein, A.; Csonka, L. Evolution of proline biosynthesis: Enzymology, bioinformatics, genetics, and transcriptional regulation. Biol. Rev. Camb. Philos. Soc. 2015, 90, 1065-1099. [CrossRef] [PubMed]

56. Strizhov, N.; Ábrahám, E.; Ökrész, L.; Blickling, S.; Zilberstein, A.; Schell, J.; Koncz, C.; Szabados, L. Differential expression of two P5CS genes controlling proline accumulation during salt-stress requires ABA and is regulated by ABA1, ABI1 and AXR2 in Arabidopsis. Plant J. 1997, 12, 557-569. [CrossRef] [PubMed]

57. Székely, G.; Ábrahám, E.; Cséplő, A.; Rigó, G.; Zsigmond, L.; Csiszár, J.; Ayaydin, F.; Strizhov, N.; Jásik, J.; Schmelzer, E.; et al. Duplicated P5CS genes of Arabidopsis play distinct roles in stress regulation and developmental control of proline biosynthesis. Plant J. 2008, 53, 11-28. [CrossRef] [PubMed]

58. Mattioli, R.; Falasca, G.; Sabatini, S.; Altamura, M.M.; Costantino, P.; Trovato, M. The proline biosynthetic genes P5CS1 and P5CS2 play overlapping roles in Arabidopsis flower transition but not in embryo development. Physiol. Plant. 2009, 137, 72-85. [CrossRef]

59. Verbruggen, N.; Villarroroel, R.; Van Montagu, M. Osmoregulation of a Pyrroline-5-Carboxylate Reductase Gene in Arabidopsis thaliana. Plant Physiol. 1993, 103, 771-781. [CrossRef] [PubMed]

60. Savouré, A.; Jaoua, S.; Hua, X.J.; Ardiles, W.; Van Montagu, M.; Verbruggen, N. Abscisic acid-independent and abscisic acid-dependent regulation of proline biosynthesis following cold and osmotic stresses in Arabidopsis thaliana. Mol. Gen. Genet. 1997, 254, 104-109. [CrossRef]

61. Verbruggen, N.; Hua, X.J.; May, M.; Van Montagu, M. Environmental and developmental signals modulate proline homeostasis: Evidence for a negative transcriptional regulator. Proc. Natl. Acad. Sci. USA 1996, 93, 8787-8791. [CrossRef]

62. Deuschle, K.; Funck, D.; Hellmann, H.; Däschner, K.; Binder, S.; Frommer, W.B. A nuclear gene encoding mitochondrial $\Delta$ 1-pyrroline-5-carboxylate dehydrogenase and its potential role in protection from proline toxicity. Plant J. 2001, 27, 345-356. [CrossRef]

63. Funck, D.; Eckard, S.; Müller, G. Non-redundant functions of two proline dehydrogenase isoforms in Arabidopsis. BMC Plant Biol. 2010, 10, 70. [CrossRef] 
64. Kiyosue, T.; Yoshiba, Y.; Yamaguchi-Shinozaki, K.; Shinozaki, K. A nuclear gene encoding mitochondrial proline dehydrogenase, an enzyme involved in proline metabolism, is upregulated by proline but downregulated by dehydration in Arabidopsis. Plant Cell 1996, 8, 1323-1335. [CrossRef] [PubMed]

65. Peng, Z.; Lu, Q.; Verma, D.P.S. Reciprocal regulation of 1-pyrroline-5-carboxylate synthetase and proline dehydrogenase genes controls proline levels during and after osmotic stress in plants. Mol. Gen. Genet. 1996, 253, 334-341. [CrossRef] [PubMed]

66. Kavi Kishor, P.B.; Hong, Z.; Miao, G.-H.; Hu, C.-A.A.; Verma, D.P.S. Overexpression of $\delta$-Pyrroline-5-Carboxylate Synthetase Increases Proline Production and Confers Osmotolerance in Transgenic Plants. Curr. Sci. 1995, 88, 1387-1394. [CrossRef]

67. Nanjo, T.; Kobayashi, M.; Yoshiba, Y.; Sanada, Y.; Wada, K.; Tukaya, H.; Kakubari, Y.; YamaguchiShinozaki, K.; Shinozaki, K. Biological functions of proline in morphogenesis and osmotolerance revealed in antisense transgenic Arabidopsis thaliana. Plant J. 1999, 18, 185-193. [CrossRef] [PubMed]

68. Mattioli, R.; Marchese, D.; D'Angeli, S.; Altamura, M.M.; Costantino, P.; Trovato, M. Modulation of intracellular proline levels affects flowering time and inflorescence architecture in Arabidopsis. Plant Mol. Biol. 2008, 66, 277-288. [CrossRef] [PubMed]

69. Funck, D.; Winter, G.; Baumgarten, L.; Forlani, G. Requirement of proline synthesis during Arabidopsis reproductive development. BMC Plant Biol. 2012, 12, 191. [CrossRef]

70. Mattioli, R.; Costantino, P.; Trovato, M. Proline accumulation in plants. Plant Signal. Behav. 2009, 4, $1016-1018$. [CrossRef]

71. Simpson, G.G.; Dean, C. Arabidopsis, the Rosetta Stone of Flowering Time? Science 2002, 296, $285-289$. [CrossRef]

72. Amasino, R.M.; Michaels, S.D. The timing of flowering. Plant Physiol. 2010, 154, 516-520. [CrossRef]

73. Andrés, F.; Coupland, G. The genetic basis of flowering responses to seasonal cues. Nat. Rev. Genet. 2012, 13, 627. [CrossRef] [PubMed]

74. Conti, L. Hormonal control of the floral transition: Can one catch them all? Dev. Biol. 2017, 430, $288-301$. [CrossRef] [PubMed]

75. Samach, A.; Onouchi, H.; Gold, S.E.; Ditta, G.S.; Schwarz-Sommer, Z.S.; Yanofsky, M.F.; Coupland, G. Distinct Roles of CONSTANS Target Genes in Reproductive Development of Arabidopsis. Science 2000, 288, 1613-1616. [CrossRef] [PubMed]

76. Hare, P.; Cress, W. Metabolic implications of stress-induced proline accumulation in plants. Plant Growth Regul. 1997, 21, 79-102. [CrossRef]

77. Smirnoff, N.; Cumbes, Q.J. Hydroxyl radical scavenging activity of compatible solutes. Phytochemistry 1989, 28, 1057-1060. [CrossRef]

78. Nunes-Nesi, A.; Fernie, A.R.; Stitt, M. Metabolic and Signaling Aspects Underpinning the Regulation of Plant Carbon Nitrogen Interactions. Mol. Plant 2010, 3, 973-996. [CrossRef]

79. Mattioli, R.; Biancucci, M.; Lonoce, C.; Costantino, P.; Trovato, M. Proline is required for male gametophyte development in Arabidopsis. BMC Plant Biol. 2012, 12, 236. [CrossRef]

80. Biancucci, M.; Mattioli, R.; Moubayidin, L.; Sabatini, S.; Costantino, P.; Trovato, M. Proline affects the size of the root meristematic zone in Arabidopsis. BMC Plant Biol. 2015, 15, 263. [CrossRef]

81. Krogaard, H.; Andersen, A.S. Free Amino-Acids of Nicotiana-Alata Anthers during Development Invivo. Physiol. Plant. 1983, 57, 527-531. [CrossRef]

82. Khoo, U.; Stinson, H.T. Free amino acid differences between cytoplasmic male sterile and normal fertile anthers. Proc. Natl. Acad. Sci. USA 1957, 43, 603-607. [CrossRef]

83. Lansac, A.R.; Sullivan, C.Y.; Johnson, B.E. Accumulation of free proline in sorghum (Sorghum bicolor) pollen. Can. J. Bot./Rev. Can. Bot. 1996, 74, 40-45. [CrossRef]

84. Lehmann, S.; Gumy, C.; Blatter, E.; Boeffel, S.; Fricke, W.; Rentsch, D. In planta function of compatible solute transporters of the AtProT family. J. Exp. Bot. 2011, 62, 787-796. [CrossRef] [PubMed]

85. Honys, D.; Twell, D. Comparative analysis of the Arabidopsis pollen transcriptome. Plant Physiol. 2003, 132, 640-652. [CrossRef] [PubMed]

86. Zhang, H.Q.; Croes, A.F. Proline metabolism in pollen - degradation of proline during germination and early tube growth. Planta 1983, 159, 46-49.

87. Biancucci, M.; Mattioli, R.; Forlani, G.; Funck, D.; Costantino, P.; Trovato, M. Role of proline and GABA in sexual reproduction of angiosperms. Front. Plant Sci. 2015, 6, 680. [CrossRef] 
88. Moubayidin, L.; Perilli, S.; Dello Ioio, R.; Di Mambro, R.; Costantino, P.; Sabatini, S. The Rate of Cell Differentiation Controls the Arabidopsis Root Meristem Growth Phase. Curr. Biol. 2010, 20, 1138-1143. [CrossRef]

89. Dello Ioio, R.; Linhares, F.S.; Scacchi, E.; Casamitjana-Martinez, E.; Heidstra, R.; Costantino, P.; Sabatini, S. Cytokinins Determine Arabidopsis Root-Meristem Size by Controlling Cell Differentiation. Curr. Biol. 2007, 17, 678-682. [CrossRef]

90. Tsukagoshi, H.; Busch, W.; Benfey, P.N. Transcriptional Regulation of ROS Controls Transition from Proliferation to Differentiation in the Root. Cell 2010, 143, 606-616. [CrossRef]

91. Stewart, C.R. The Mechanism of Abscisic Acid-induced Proline Accumulation in Barley Leaves. Plant Physiol. 1980, 66, 230-233. [CrossRef]

92. Ábrahám, E.; Rigó, G.; Székely, G.; Nagy, R.; Koncz, C.; Szabados, L. Light-dependent induction of proline biosynthesis by abscisic acid and salt stress is inhibited by brassinosteroid in Arabidopsis. Plant Mol. Biol. 2003, 51, 363-372. [CrossRef]

(C) 2018 by the authors. Licensee MDPI, Basel, Switzerland. This article is an open access article distributed under the terms and conditions of the Creative Commons Attribution (CC BY) license (http://creativecommons.org/licenses/by/4.0/). 